\title{
Sexuality Education in Christian Homes: Knowledge and Perception of Young People in Ife Central Local Government Osun State
}

\author{
Ogunsanmi Ololade $^{1}$, Afolabi Ibukunoluwa ${ }^{2}$ Olaoye Titilayo $^{3}$, Ajike Saratu ${ }^{4}$ \\ ${ }^{1,2,3,4}$ Department of Public Health, School of Public and Allied Health, Babcock University, Ogun State, Nigeria
}

\begin{abstract}
Parents are the most important resource persons in preparing young people for adulthood but they often have difficulties communicating about sex. These skills should greatly foster young people to develop individual values and make healthy decisions. The study employed a descriptive study design; 400 young people (15-24 years old) were selected randomly from six (6) different churches. Data was gathered with a questionnaire with reliability coefficient 0.73 and analyzed using SPSS software (version 21). Results showed a high level (91.8\%) of sex education knowledge; more than half (55\%) were between 15 to 19 years; $52 \%$ were females and $75 \%$ of respondents' parents were educated at the tertiary level. Only 73 (18\%) of the respondents were educated about sex at home often and 99 (24.8\%) never did. It can thus be concluded that the prevalence of sexuality communication between young people and their parents in Christian homes is low. Programs that would help parents positively develop healthy communication skills should be developed to reduce the burden of negative sexual outcomes among young people.
\end{abstract}

Keywords: Sex education, parents, young people

\section{Introduction}

In many African countries, talking about sex is forbidden and considered unnecessary till adulthood or marriage. Most African children are taught to abstain from sexuality talks because these might encourage promiscuity and wayward acts. Past researches revealed that the teaching of sex education to adolescents has continued to pose as a problem in Nigeria because both literate and illiterate parents share the same cultural and religious beliefs [1], [2]. Unawares to many, Sexual Education (SE) is an effective tool in preventing unwanted pregnancies, spread of Sexually Transmitted Infections (STIs) and many other sexuality issues. Sex education (SE) has been defined as the provision of straightforward and elemental information about the anatomy, physiology and psychology of sex, and relating this to practical issues that normally affect adolescents, like contraception, abortion and STI [3].

Children and young people have to be prepared for the transition to adulthood and this happens to be one of the greatest challenges faced around the world. Today, in a world with AIDS, the how we meet this challenge is our most important opportunity in breaking the tragedy of the epidemic [4]. Studies in the past have shown that over $90 \%$ of adolescents and young adults in Nigeria have become sexually active by the age of 20 years and a large proportion of these occurred in casual and non-conjugal relationships, thereby increasing their vulnerability to several sexual and reproductive problems [5]. Secondary school students often become sexually active even at a tender age of 9 years [6] and by the time young people turn age 20 , more than three quarters of Nigerian girls and boys have had sexual intercourse [7].

The role of parental guidance in sex education should not be underestimated because parents are the first group of people who set moral standards for their children. They operate as role models to their children. When parents are permissive in their parenting style, it exposes adolescents into pre-marital sex [2]. Research has shown that adolescents constantly want to receive sexuality information from both their parents and teachers. Parents and children have believed that teaching of sexuality issues would indeed go a long way in reducing the incidence of unwanted pregnancy and other sexuality issues [8], [9].

Evidence shows that SE works best if it starts before a young person has their first experience of sex and if it responds to the needs of young people as they mature. SRE must start in primary school and be taught in an age-appropriate manner, starting with topics such as personal safety and friendships. Primary and secondary school pupils, particularly girls, have said they need SRE to start earlier [10].

Lack or inadequate sex education puts young people at risk of STDs including HIV/AIDS and unplanned pregnancy which pushes them to perform or seek an abortion which is actually illegal in Nigeria [11], except to save a woman's life [12].

In addition to learning about human development, reproductive health and sexual health, as part of sexuality education, young people gain information about self-efficacy in adopting safer sex practices, they get comfortable in discussing sexuality issues subsequently and they learn about the reproductive health outcomes of unwanted pregnancies and STIs. This knowledge gives them the basis for positive mental and reproductive health and well-being and introduces them to skills that they can build on as they grow [13].

\section{Methods}

The research was descriptive in design and the population of study was young people between the ages of 10-24 in 


\section{International Journal of Science and Research (IJSR) \\ ISSN (Online): 2319-7064 \\ Index Copernicus Value (2013): 6.14 | Impact Factor (2014): 5.611}

different churches in Ife Central Local Government Area of Osun State. Six (6) churches (3 orthodox and 3 Pentecostal churches) had been picked through balloting and from these, four hundred (400) respondents were randomly selected. One Orthodox Church as well as one Pentecostal church was that was not part of the sample were used to get the reliability coefficient.

The instrument for data collection, which was a selfadministered questionnaire, had been pre-tested among 40 young people who were non-respondents. Pearson Product Moment Correlation analysis was used to analyze and a coefficient of 0.73 was gotten at 0.05 level of significance. Oral consent was gotten from each respondent before questionnaire administration and respondents were informed of the purpose of the study and guidelines involved in the input of information in the questionnaire. After the data was collected it was entered and coded. Using the Statistical Package of Social Sciences (SPSS) version 21.0, data analysis was carried out with univariate (frequencies, descriptives) and bivariate test analysis (correlation) to determine relationships between variables of choice.

\section{Results}

Almost 53\% (210) of the respondents were females and 64\% (219) were between the ages of 15-19 (Table 1). Only 9 $(2.3 \%)$ of the young people had only primary education, $16.3 \%$ (65) had secondary education and $81.5 \%$ (326) had tertiary education. Distribution from the six (6) different churches showed $7.3 \%$ (29) from the Roman Catholic church, 2.8\% (11) from Seventh-Day Adventist church, 29.3\% (117) from Deeper Life Bible Church, 19.5\% (76) from Baptist Church, 4.8\% (19) from Living Faith Church with majority (146;36.5\%) from the Redeemed Christian Church of God. About 16.0\% (64) of the respondents had single parents, $68.0 \%$ (272) had married parents, $4.0 \%$ (16) had divorced parents, $3.5 \%$ (14) had separated parents and $8.5 \%$ (34) had widowed parents. The vast majority of the young peoples' parents $(75.5 \%)$ had tertiary education with the remainder with either primary $(6.8 \%)$ or secondary $(17.8 \%)$ education.

Table 1: Percentage Distribution of Young People from Christian Homes by Selected Characteristics

\begin{tabular}{|c|c|}
\hline VARIABLES & FREQ (\%) \\
\hline Age & \\
$10-14$ & $24(6.0 \%)$ \\
$15-19$ & $219(54.8 \%)$ \\
$20-24$ & $157(39.3 \%)$ \\
\hline Sex & \\
Male & $190(47.5 \%)$ \\
Female & $210(52.5 \%)$ \\
\hline Educational Background & \\
Primary & $9(2.3 \%)$ \\
Secondary & $65(16.3 \%)$ \\
Tertiary & $326(81.5 \%)$ \\
\hline Denomination & \\
Roman Catholic & $29(7.3 \%)$ \\
SDA & $11(2.8 \%)$ \\
RCCG & $146(36.5 \%)$ \\
Deeper life & $117(29.3 \%)$ \\
Baptist & $74(19.5 \%)$ \\
\hline
\end{tabular}

\begin{tabular}{|c|c|}
\hline Living faith & $19(4.8 \%)$ \\
\hline Marital Status of Parents & \\
Single & $64(16.0 \%)$ \\
Married & $272(68.0 \%)$ \\
Divorced & $16(4.0 \%)$ \\
Separated & $14(3.5 \%)$ \\
Widowed & $34(8.5 \%)$ \\
\hline Parent's Educational level & \\
Primary & $27(6.8 \%)$ \\
Secondary & $71(17.8 \%)$ \\
Tertiary & $302(75.5 \%)$ \\
\hline Parent's Occupation & \\
Civil Servant & $220(55.0 \%)$ \\
Private Enterprise & $51(12.8 \%)$ \\
Self Employed & $129(32.3 \%)$ \\
\hline
\end{tabular}

Majority of the respondents $(91.8 \% ; 367)$ reported to have had sex education prior to the study (Table 2). Respondents indicated that sex education taught them physical change during puberty $(61.5 \%)$, sexual reproduction $(43.0 \%)$, contraceptives $(43.5 \%)$, relationship (love \& commitment) $(29.3 \%)$, laws related to sexual behavior $(29.3 \%)$ and religious and cultural laws on sex (46.8\%). Respondents who have been educated on sex at home at one time or the other were $73.0 \%$ (292), while $27 \%$ (108) have never been educated on sex by their parents. Out of 400 respondents, $86 \%$ (344) of the respondents had no religious or cultural belief that forbids sex education in their homes, while $14.0 \%$ (56) had.

Table 2: Percentage Distribution of Frequency and Knowledge of Young People from Christian Homes Regarding Sex Education Practice

\begin{tabular}{|l|c|}
\hline \multicolumn{1}{|c|}{ VARIABLES } & $F R E Q(\%)$ \\
\hline Have you ever been educated about sex? & $367(91.8)$ \\
Yes & $33(8.3)$ \\
No & \\
\hline What do you learn from sex education? & \\
Physical change during puberty & $246(61.5)$ \\
Yes & $154(38.5)$ \\
No & $172(43.0)$ \\
Sexual reproduction & $228(57.0)$ \\
Yes & $150(37.5)$ \\
No & $250(62.5)$ \\
Contraceptives & $174(43.5)$ \\
Yes & $226(56.5)$ \\
No & $117(29.3)$ \\
Relationship (love \& commitment) & $283(70.8)$ \\
Yes & \\
No & $187(46.8)$ \\
Laws related to sexual behavior & $213(53.3)$ \\
Yes & \\
No & $292(73.0)$ \\
Religious and cultural laws on sex & $108(27.0)$ \\
Yes & \\
No & $56(14.0)$ \\
\hline Do your parents educate you on sex & $344(86.0)$ \\
Yes & \\
No & \\
Is there a cultural or religious law that \\
forbids sex education your home \\
Yes & \\
No & \\
\hline
\end{tabular}

Seventy eight percent (312) of the respondents agreed that 


\section{International Journal of Science and Research (IJSR) \\ ISSN (Online): 2319-7064 \\ Index Copernicus Value (2013): 6.14 | Impact Factor (2014): 5.611}

sex education should be given by both parents at home, while $20.5 \%(82)$ said sex education should be given by the mother and $1.5 \%$ (6) said it should be given by the father (Table 3 ).

Also, $83.0 \%$ (332) agreed that adolescents should be educated about sex at home, while $17.0 \%$ (68) said sex education should be gotten from the school. More than half $(53.0 \%)$ of the respondents said sex education should begin between 11-15 years of age 32.5\% (130) said between 5 and 10 years, while $14.5 \%$ (58) said between 16 and 20 years. About 50.3\% (201) clarify their doubts about sex from their friends, $42.0 \%$ (168) from parents and $7.8 \%$ (31) from their siblings.

Almost a fifth $(18.3 \% ; 73)$ of the respondents receive sex education from the home very often, $14.3 \%$ (27) rarely receive sex education at home, $42.8 \%$ (171) have sex education at home once in a while and $24.8 \%$ (99) have never had sex education at home (Table 4).

Table 3: Percentage Distribution of Young People from Christian Homes by Responses to Perception about Sex

\begin{tabular}{|c|c|c|c|}
\hline \multicolumn{4}{|c|}{ Education } \\
\hline VARIABLES & & $F R E Q(N)$ & PER (\%) \\
\hline \multirow{3}{*}{$\begin{array}{l}\text { Preferred sex educator in } \\
\text { home }\end{array}$} & Father & 6 & 1.5 \\
\hline & Mother & 82 & 20.5 \\
\hline & Both & 312 & 78 \\
\hline \multirow{2}{*}{$\begin{array}{c}\text { Location for adolescent sex } \\
\text { education }\end{array}$} & Home & 332 & 83 \\
\hline & Schools & 68 & 17 \\
\hline \multirow{3}{*}{$\begin{array}{c}\text { Age of sex education } \\
\text { inception }\end{array}$} & 10-May & 130 & 32.5 \\
\hline & $15-\mathrm{Nov}$ & 212 & 53 \\
\hline & $16-20$ & 58 & 14.5 \\
\hline \multirow{3}{*}{$\begin{array}{l}\text { Persons to help clarify doubts } \\
\text { on sex education }\end{array}$} & Friends & 201 & 50.3 \\
\hline & Siblings & 31 & 7.8 \\
\hline & Parents & 168 & 42 \\
\hline
\end{tabular}

Table 4: Percentage Distribution of Respondents by the Frequency of Sex Education

\begin{tabular}{|c|c|c|c|}
\hline Variables & & FREQ (N) & PER (\%) \\
\hline \multirow{4}{*}{$\begin{array}{c}\text { How often do } \\
\text { you have sex } \\
\text { education at } \\
\text { home }\end{array}$} & Very often & 73 & 18.3 \\
\hline & Rarely & 57 & 14.3 \\
\hline & Once in a while & 171 & 42.8 \\
\hline & Never & 99 & 24.8 \\
\hline
\end{tabular}

\section{Discussion}

The knowledge of those that have heard of sex education at one point or the other is quite high $(91.8 \%)$. Majority $(64.3 \%)$ as observed in this study are more familiar with the abstinence-only type of sex education as the only way of preventing teenage pregnancy and other STIs. This is similar to results of a research carried out in which stated that most parents and religious organizations promote the abstinence only sex education, and little or no effort is made to educate them on comprehensive sex education [14].

As observed in this research, respondents first found out about sex in school, from the media, their mothers, friends, fathers and siblings. From previous studies [15], [16] it was observed that some parents really want to educate their wards about sex but they lack the skills and competency to do so and some do not do it because they think they are introducing their children to sex. So, this pushes the children to get adulterated information from other sources.

This research shows that $84.0 \%$ affirmed that there is no cultural or religious belief that forbids sex education in their homes and $92.0 \%$ agreed that sex should be discussed in Christian homes. This implies that sex education can be taught in Christian homes.

This research revealed that $57.7 \%$ of the young people do not feel comfortable discussing their relationships they have with the opposite sex with their parents. It is observed in previous studies [17] that parents do not initiate good communication with their children from an early age, thereby monitoring their activities and help in shaping both their behavior and social context as they grow up. So, this is one of the factors why young people do not have a good rapport to be able to discuss their relationship with the opposite sex with their parents.

\section{Conclusion}

There is an urgent need to equip young people with skills they need for a healthy and fulfilling adult life. Young people should have comprehensive sexuality education that provides consistent and accurate information at their disposals. This can help build positive attitudes and behavior as well as building their decision making skills. A good partnership between parents and schools will ensure sound and solid sexuality education programs.

\section{References}

[1] A. Esu, "Sex education in Nigerian Schools", in Contemporary Issues in Nigerian Education and Development, D. N. Nwachukwu (ed), Enugu: Sam \& Star Group of Company, 1990.

[2] A. I. Isangedighi, "Adolescents Sexuality in Nigerian Society", in Contemporary Issues in Nigerian Education and Development, D. N. Nwachukwu (ed), Enugu: Sam \& Star Group of Company, 1990.

[3] S. Crown, "Psychosexual problems", Counseling and Behavioral Modification, London: Academic Press, 1976.

[4] UNESCO, "Youth and comprehensive sexuality education". http://www.unesco.org/new/en/hiv-andaids/our-priorities-in-hiv/sexuality-education. [Accessed: Sept. 25, 2015]. (General Internet site)

[5] I. A. Onwuezobe, "The attitude of Teachers to Sexuality Education in Lagos State, Nigeria" Master of Public Health Project (Unpublished).7-27, 2005.

[6] B. O. Idonije, O. M. Oluba, \& H. O. Otamere, "A Study on Knowledge, Attitude and Practice of Contraception among Secondary School Students in Ekpoma, Nigeria", JPCS, (2) pp. 22-27, 2011.

[7] P. Makinwa-Adebusoye. "Sexual Behavior, Reproductive Knowledge and Contraceptive Use among Young Urban Nigerians", International Family Planning Perspective, (18), pp. 67-69, 1992. 
[8] L. O. Ogunjimi, "Attitude of Students and Parents towards the Teaching of Sex Education in Secondary Schools in Cross Rivers State", Educational Research and Review, 1(9). pp. 347-34, 2006.

[9] A. A. Akande, and T. M. Akande, "Knowledge and Perception of Sexuality Education among Students of a Rural Secondary School in Kwara State, Nigeria", Nigerian Medical Practitioner, 52(3), pp. 55-59, 2007.

[10] Ofsted, "Personal, social, health and economic education in schools",ofsted.gov.uk/resources/090222 [Accessed: Sept. 27, 2015], (General Internet site)

[11]T. A. Oyebode, A. S. Sagay, I. H. Shambe, A. O. Ebonyi, C. O. Isichei, B. O. Toma, H.Y. Embu, P. H. Daru, and I. A. Ujah, "The Contribution of Unsafe Abortions to Gynaecological Emergencies and Mortality-Five Year Experience of Jos University Teaching Hospital, Nigeria". International Journal of Biomedical Research, 6(06): pp. 402-411, 2015.

[12] A. Bankole, I. F. Adewole, R. Hussain, O. Awolude, S. Singh and J. O. Akinyemi, "The incidence of Abortion in Nigeria", International Perspectives on Sexual and Reproductive Health, (41:4), pp. 170-181, 2015.

[13] A .J. Ajuwon, "Benefits of Sexuality Education for Young People in Nigeria", in Human Sexuality in Africa, Maticka-Tyndale, Tiemoko \& MakinwaAdebusoye (eds) Fanele Publishers, pp. 67-82, 2007.

[14]S. Alford, "Science and Success", Second Edition: Programs that Work to Prevent Teen Pregnancy, HIV \& Sexually Transmitted Infections. Washington, DC: Advocates for Youth, 2008.

[15]T. D. Afifi, A. Joseph \& D. Aldeis, "Why Can't We Just Talk About It? An Observational Study of Parents' and Adolescents' Conversations about Sex", Journal of Adolescent Research, 23(6), pp. 689-721, 2008.

[16] J. L. Kim \& L. M. Ward, "Silence Speaks Volumes: Parental Sexual Communication among Asian American Emerging Adults", Journal of Adolescent Research 22(1), pp. 3-31, 2007.

[17] A. Biddlecom, K. Awusabo-Asare and A. Bankole, "Role of Parents in Adolescent Sexual Activity and Contraceptive Use in Four African Countries", International Perspectives on Sexual and Reproductive Health. 35(2), pp. 72-81, 2009. 